\title{
ANALISIS USAHA PETERNAKAN BABI PADA PERUSAHAN "KASEWEAN" KAKASKASEN II KOTA TOMOHON
}

\author{
Zadrak M. Warouw*, V. V. J. Panelewen** dan Arie Dp. Mirah** \\ Fakultas Peternakan Universitas Sam Ratulangi Manado, 95115
}

\begin{abstract}
ABSTRAK
Penelitian ini bertujuan untuk menganalisis berapa besar biaya produksi dan keuntungan serta titik impas usaha peternakan babi pada perusahaan "Kasewean" di Kakaskasen II Kota Tomohon. Metode penelitian adalah metode survey dengan pendekatan studi kasus. Hasil penelitian menunjukkan komposisi biaya selama proses produksi per periode yaitu biaya pakan sebesar $44,66 \%$, biaya tenaga kerja $14,80 \%$, biaya bibit $22,61 \%$, penyusutan kandang/peralatan $0,90 \%$, listrik/air $0,79 \%$, transportasi $14,80 \%$ dan pajak atas usaha sebesar $0,96 \%$ dari keseluruhan biaya produksi. Kesimpulannya ialah rata-rata biaya produksi usaha peternakan babi pada sebesar Rp. 1.136.863 per ekor per periode produksi yang terdiri dari biaya tetap sebesar Rp. 278.093 dan biaya tidak tetap sebesar Rp. 858.770 per ekor per periode produksi. Penggunaan modal (biaya produksi) sudah efisien dilihat dari nilai ROI sebesar 1.51. Usaha peternakan babi pada perusahaan "Kasewean" memperoleh keuntungan yang signifikan dilihat dari rata-rata keuntungan yang diperoleh sebesar Rp. 580.932 per ekor per periode produksi dan rata-rata keuntungan per bulan sebesar Rp. 15.539.943. Perusahaan sudah mencapai bahkan sudah berproduksi di atas nilai titik impas pada volume produksi 103,92 unit atau 103 ekor dengan tingkat penerimaan $\mathrm{Rp}$. 178.509.314 per periode produksi.
\end{abstract}

\footnotetext{
*Mahasiswa PPS Unsrat

**Jurusan Sosial Ekonomi Peternakan
}

\author{
Kata Kunci : Peternakan Babi, \\ keuntungan, biaya, BEP
}

\section{ABSTRACT}

PIG FARM ANALYSIS OF KASEWEAN COMPANY AT KAKASKASEN II OF TOMOHON MUNICIPALITY. The objective of this study were to find cost production, benefit and break even point of pig farming in Kasewean enterprise located in Tomohon city. The Results of the study showed that, Kasewean enterprise had breakeven Point on pig farming at 103103 heads, and the income level was Rp. 178.509.314/period of production. Value of the breakeven point could be seen through the value Margin Of Safety (MOS) of $67.62 \%$, meaning that if the rate of production decreased by $67.63 \%$, the pig farm is still in state of breakeven point, then the MOS value can be explained by Return Of Invesment (ROI). ROI obtained a value of 1.51. This means that the use of capital (cost of production) on a pig farm "Kasawean" in Tomohon already at efficient scale or provide the level of profit. Conclusions were (1) The average cost of production of pig farming in Kasewean company Tomohon was 1.136.863/head/production period consisted of a fixed cost of Rp. 278.093 of a fixed cost and Rp. $858.770 /$ heads/production period of variable cost with the value of ROI was 1.51 which means the use of capital (cost of production) of pig farm on the 
"Kasewean" company in Tomohon already efficient, (2) Pig farm on the "kasewean" company obtained significant profit because the everage income was Rp. $580.932 /$ head/production period and the average monthly profit was Rp. 15.539.943. and (3) Animal farm on "Kasewean" company has reached the value above breakeven point of 103.92 on production volume of 103 units or heads with turnover level of Rp. 178.509.314/production period

Key Words : Pig farming, benefit, cost, breakeven point

\section{PENDAHULUAN}

Keterbatasan modal yang dimiliki peternak mengakibatkan mereka membatasi jumlah ternak yang dipelihara dan penggunaan faktor input sehingga akan berdampak pada tingkat keuntungan yang relatif kecil. Menurut Sihombing (2010), biaya produksi terbesar dalam usaha ternak babi ialah biaya makanan mencapai $65-80$ persen dari total biaya produksi. Sementara pada kenyataannya akhirakhir ini semenjak krisis moneter melanda perekonomian, harga bahan pakan ternak mengalami peningkatan. Adanya kenaikan biaya produksi tanpa diikuti dengan keuntungan merupakan masalah bagi peternak karena biaya produksi merupakan faktor penentu dalam usaha peternakan. Perubahan harga faktor produksi tentunya akan berdampak pada perubahan keuntungan yang diterima. Dalam setiap usaha peternakan selalu mengharapkan keuntungan sebab keberhasilan usaha peternakan banyak tergantung dari keuntungan yang diperoleh peternak. Terdapat beberapa keuntungan yang dapat diperoleh dalam beternak babi, selain sebagai sumber protein juga dapat memberikan sumbangan yang besar bagi peningkatan pendapatan keluarga peternak.

Upaya peningkatan keuntungan membutuhkan perhitungan penggunaan biaya faktor produksi dalam usaha ternak babi. Khususnya usaha peternakan babi pada perusahaan "Kasewean" Kakaskasen II Tomohon sudah cukup lama beroperasi sehingga diperlukan suatu kajian analisis penggunaan biaya produksi sebagai faktor input dalam hubungannya dengan perolehan keuntungan. Permasalahannya apakah penggunaan biaya produksi dalam usaha peternakan babi sudah efisien sehingga memberikan keuntungan yang signifikan dan apakah usaha peternakan babi pada perusahaan 
"Kasewean" di Kakaskasen II Kota Tomohon sudah mencapai titik impas. Penelitian ini bertujuan untuk menganalisis berapa besar biaya produksi dan keuntungan serta titik impas usaha peternakan babi pada perusahaan "Kasewean" di Kakaskasen II Kota Tomohon.

\section{MATERI DAN METODE PENELITIAN}

Penelitian ini dilaksanakan pada usaha peternakan babi perusahaan "Kasewean" milik Keluarga Mamuaja yang sudah diwariskan kepada anak Kel. Sambouw Mamuaja berlokasi di Kakaskasen II Kota Tomohon. Penelitian ini menggunakan metode survey dengan pendekatan studi kasus (Arikunto, 2002; Daniel, 2001; Singarimbun dan Effendi, 2009). Studi kasus ialah studi yang dilakukan terhadap suatu subjek dalam menjajaki suatu aktivitas untuk memperoleh fakta dan data. Jenis data yang dikumpulkan dalam penelitian ini terdiri atas data sekunder dan data primer. Data sekunder diperoleh dari instansi, seperti dinas Agribisnis Kota Tomohon, kantor kelurahan maupun pihak yang ada kaitannya dengan penelitian ini (seperti poultry shop). Data primer diperoleh melalui wawancara langsung pada responden yaitu pemilik usasa peternakan babi perusahaan "Kasewean". Data primer meliputi; karakteristik usaha peternakan, populasi ternak babi, produksi, harga, biaya tetap, biaya variabel selama satu periode produksi atau dalam satu tahun. Definisi variabel dan pengukurannya yaitu (1) Biaya tetap ialah keseluruhan biaya tetap yang dikorbankan untuk usaha peternakan babi antara lain; biaya bibit ternak babi, penyusutan kandang/peralatan dan pajak usaha yang dinyatakan dalam satuan rupiah per periode produksi; (2) Biaya variabel ialah keseluruhan biaya operasional antara lain; biaya makanan, tenaga kerja, obat-obatan/vaksin dan vitamin, transportasi, rekening listrik dan air yang dikorbankan, dinyatakan dalam satuan rupiah per periode produksi; (3) Penerimaan ialah hasil penjualan ternak babi dikalikan dengan harga, dinyatakan dalam satuan rupiah per periode; (4) Keuntungan ialah jumlah uang yang diperoleh sebagai selisih antara penerimaan dengan 
biaya operasional (biaya variabel), dinyatakan dalam satuan rupiah per periode produksi. Data yang dikumpulkan di tabulasi dan di analisis dengan menggunakan pendekatan analisis deskriptif dan matematik yaitu analisis biaya produksi dan keuntungan serta analisis titik impas. Pendekatan analisis deskriptif dimaksudkan untuk menguraikan secara kualitatif keadaan riil peternakan babi perusahaan "Kasewean” Kakaskasen II Kota Tomohon yang diformulasikan dalam bentuk tabelaris ataupun persentase. Analisis tingkat keuntungan menggunakan model analisis profit (Beattie and Taylor, 1994; Derbertin, 1986). Perbandingan antara penerimaaan dengan biaya produksi yang dikorbankan selama proses produksi, dianalisis melalui pendekatan Return of Investment (ROI) ialah :

$$
\text { ROI }=\frac{\text { Laba Usaha }}{\text { Total biaya produksi }}
$$

Jika nilai $\mathrm{ROI}>1$, berarti usaha tersebut menguntungkan. Semakin besar nilai ROI akan semakin besar pula tingkat keuntungan yang diperoleh dari usaha tersebut dan dapat dikategorikan makin efisien penggunaan modal dari suatu usaha. Analisis titik impas menggunakan pendekatan analisis menurut Ibrahim (2003) bahwa, analisis titik impas atau break even point (BEP) ialah total revenue (TR) sama dengan total cost (TC). Analisis titik impas dihitung berdasarkan volume, produksi (unit) dan penerimaan (rupiah) dengan model pendekatan BEP Unit dan BEP Rupiah sebagai berikut :

$$
\begin{aligned}
& B E P(\text { unit })=\frac{T F C}{H Y-V C} \\
& B E P(\text { Rupiah })=\frac{T F C}{1-\frac{V C}{H Y}}
\end{aligned}
$$

Perusahaan masih berada pada situasi tidak merugi dalam beroperasi, dianalisis melalui pendekatan Margin Of Safety (MOS) yaitu penurunan persentase produksi yang aman atau besarnya penurunan produksi suatu usaha. Model analisis MOS ialah nilai penjualan yang dianggarkan (nilai penerimaan produksi) dikurangi dengan nilai titik impas diperbandingkan dengan nilai penjualan yang dianggarkan (nilai penerimaan produksi) yang dinyatakan dalam persentase. Pada 
umumnya MOS dinyatakan dalam ratio (persentase), yaitu :

$$
\text { MOS }=\frac{\text { Penerimaan }- \text { Titik impas }}{\text { Penenerima an }} \times 100
$$

\section{HASIL DAN PEMBAHASAN}

Biaya produksi dalam usaha peternakan babi perusahan Kasewean Tomohon meliputi biaya tetap dan biaya tidak tetap. Menurut Soekartawi (2001), bahwa biaya yang diperuntukan bagi pembiayaan faktor produksi yang sifatnya tetap seperti pembelian bibit, penyusutan dan peralatan usaha produksi maupun pajak atas usaha, sedangkan biaya tidak tetap ialah biaya yang diperuntukan bagi pembiayaan faktor produksi yang sifatnya berubah-ubah dalam satu proses produksi seperti biaya tenaga kerja maupun sarana produksi.

Biaya tetap pada usaha peternakan babi di perusahaan "Kasewean" meliputi; biaya penyusutan kandang dan peralatan serta perlengkapan kandang (sekop, ember, sapu, tempat makan dan minum, tali, dll), biaya bibit dan pajak atas usaha. Biaya tidak tetap meliputi; biaya tenaga kerja, biaya pakan dan vitamin serta obat-obatan, transportasi, rekening listrik dan air. Komposisi biaya pada peternakan babi perusahaan "Kasewean" dapat dilihat pada Tabel 3. Data pada Tabel 3 menunjukkan bahwa, biaya tetap sebesar Rp. 89.267.930 atau $24,46 \%$ dari keseluruhan biaya produksi, sedangkan biaya tidak tetap sebesar Rp. 275.665.250 atau $75,58 \%$ dari keseluruhan biaya produksi. Berdasarkan hasil penelitian, masing-masing komposisi biaya selama proses produksi per periode khususnya biaya pakan sebesar $44,66 \%$, biaya tenaga kerja sebesar $14,80 \%$, biaya bibit $22,61 \%$, penyusutan kandang dan peralatan 0,90\%, listrik \& air 0,79\%, transportasi $14,80 \%$ dan pajak atas usaha sebesar $0,96 \%$ dari keseluruhan biaya produksi. Biaya pakan hanya menyerap 44,66\% dari keseluruhan biaya produksi, hal ini tidak sesuai dengan penelitian sebelumnya yang menunjukkan biaya pakan berkisar 60-80\%. Rendahnya biaya pakan ini disebabkan karena cara pemeliharaan yang bersifat tradisional. Aritonang (2010) menyatakan bahwa biaya pakan mempunyai persentase 
terbesar dari keseluruhan biaya produksi yaitu 60-80\%. Hasil penelitian Hardyastuti (2011) menunjukkan bahwa biaya pakan untuk ternak babi berkisar antara 70$80 \%$ dari keseluruhan biaya produksi. Santa (2012) yang melakukan penelitian di Kabupaten Minahasa menunjukkan bahwa biaya pakan melebihi $80 \%$ dari keseluruhan biaya produksi.Rata-rata biaya tenaga kerja sebesar Rp. 168.224/ekor dan biaya pakan Rp. 513.350/ekor, sedangkan rata-rata biaya tetap Rp. 278.093/ekor dan rata-rata biaya tidak tetap $\mathrm{Rp}$. 858.770/ekor. Rata-rata biaya per ekor dalam usaha ternak babi pada perusahaan "Kasewean" Tomohon sebesar Rp. 1.136.863 per periode produksi per tahun. Harga jual ternak babi oleh peternak baik kepada para pedagang maupun kepada konsumen Penjualan ternak babi starter juga makin lebih baik karena menghindari dari biaya oprasional seperti biaya pakan yang cenderung berfluktuasi disebabkan harga bahan pakannya yang sering tidak stabil. Besarnya keuntungan dalam usaha peternakan babi di perusahaan "Kasewean" Tomohon selang satu periode akhir dihitung berdasarkan kilogram berat hidup untuk ternak babi potong. Ternak babi fase starter dijual per ekor dengan harga pasar yang berlaku. Jumlah ternak babi terjual, berat hidup dan penerimaan penjualan ternak babi di perusahaan peternakan babi "Kasewean" dapat dilihat pada Tabel 1. Rata-rata harga penjualan merupakan harga yang diberlakukan oleh peternak dan disesuaikan dengan harga yang berlaku di pasar Kota Tomohon. Hasil penelitian menunjukkan bahwa harga tersebut diberlakukan sama kepada pedagang pengumpul, pedagang pengecer maupun kepada konsumen akhir. Penjualan ternak fase strarter dilakukan karena ternak fase starter dijadikan bibit oleh para pembeli. Pembeli adalah peternak babi yang ada di luar Kota Tomohon.

produksi per tahun dapat dilihat pada Tabel 2. Hasil analisis diperoleh bahwa, rata-rata besarnya keuntungan yang diperoleh peternak sebesar Rp.580.932/ekor/periode produksi. Rata-rata keuntungan per bulan sebesar Rp. 15.539.943. Besarnya keuntungan yang diterima oleh peternak babi pada 
peruskahaan "Kasewean” sangat signifikan.

Hasil Analisis Titik Impas (unit), Titik Impas (rupiah) dan Margin Of Safety (MOS) serta Return Of Investment (ROI) pada Usaha Peternakan Babi di Perusahan "Kasewean" Tomohon dapat dilihat pada Tabel 4. Hasil analisis seperti pada Tabel 4 menunjukkan bahwa usaha peternakan babi di perusahan
"Kasewean" mencapai titik impas pada nilai volume produksi 103,92 unit atau 103 ekor dengan penerimaan Rp. 178.509.314/periode produksi. Hal ini mengindikasikan bahwa usaha peternakan babi di perusahan "Kasewean" Tomohon memperoleh tingkat keuntungan yang baik, artinya sudah melampaui titik impas.

Tabel 1. Jumlah Ternak Babi Terjual, Rata-Rata Berat Hidup Ternak Babi Per Ekor dan Penerimaan

\begin{tabular}{|c|c|c|c|c|}
\hline No. & Uraian & $\begin{array}{l}\text { Jumlah } \\
\text { (Ekor) }\end{array}$ & $\begin{array}{c}\text { Berat } \\
\text { Hidup } \\
\text { (Kg/Ekor) }\end{array}$ & $\begin{array}{l}\text { Jumlah } \\
\text { (Rp) }\end{array}$ \\
\hline 1. & Fase Starter (@.Rp.650.000/ekor) & 105 & 25 & 68.250 .000 \\
\hline 2. & Fase Grower (@.Rp.20.500/Kg Hidup) & 85 & 65 & 113.262 .500 \\
\hline 3. & Fase Finisher (@.Rp.22.500/Kg Hidup) & 80 & 95 & 171.000 .000 \\
\hline 4. & Induk Betina (@.Rp.26.000/Kg Hidup) & 45 & 150 & 175.500 .000 \\
\hline \multirow[t]{2}{*}{5.} & Pejantan (@.Rp.30.000/Kg Hidup) & 6 & 130 & 23.400 .000 \\
\hline & J u m la h: & 321 & 465 & 551.412 .500 \\
\hline
\end{tabular}

Tabel 2. Rata-Rata Keuntungan Usaha Peternakan Babi di Perusahan "Kasewean"

\begin{tabular}{clr}
\hline No. & \multicolumn{1}{c}{ Uraian } & Jumlah (Rp) \\
\hline 1 & Modal/Biaya Tetap (Variable Fixed Cost) & 89.267 .930 \\
2 & Biaya Tidak Tetap (Variable Cost): & 275.665 .250 \\
& Total Biaya & 364.933 .180 \\
3 & Penerimaan Penjualan Ternak (Rp) & \\
& Fase Starter (70 Hari) & 68.250 .000 \\
& Fase Grower (90 hari) & 113.262 .500 \\
& Fase Finisher (120 hari) & 171.000 .000 \\
& Induk Betina (>3 Thn) & 175.500 .000 \\
& Pejantan (>4 Thn) & 23.400 .000
\end{tabular}


Total Penerimaan $(\mathrm{Rp})$ :

551.412 .500

Rata-rata Penerimaan Per Bulan

45.951 .042

Rata-rata Penermaan Per Hari

1.531 .701

Rata-rata Penerimaan Per Ekor

1.717 .796

4 Keuntungan Per Tahun (Rp) :

186.479 .320

Rata-rata Keuntungan Per Bulan

15.539 .943

Rata-rata Keuntungan Per Hari

517.998

Rata-rata Keuntungan Per Ekor

580.932

Tabel 3. Komposisi Biaya tetap dan Biaya Tidak Tetap Pada Usaha Peternakan Babi di Perusahaan Kasewean Tomohon

\begin{tabular}{|c|c|c|c|}
\hline No & Uraian Biaya & Jumlah $(\mathrm{Rp})$ & Persentase $(\%)$ \\
\hline \multirow[t]{5}{*}{1} & Biaya Tetap (Fixed Cost): & & \\
\hline & Bibit Ternak & 82.500 .000 & 22,61 \\
\hline & Penyusutan Kandang \& Peralatan & 3.267 .930 & 0,90 \\
\hline & Pajak Usaha & 3.500 .000 & 0,96 \\
\hline & Jumlah Biaya Tetap : & 89.267 .930 & 24,46 \\
\hline \multirow[t]{13}{*}{2} & Biaya Tidak Tetap (Variable Cost): & & \\
\hline & a. Tenaga Kerja & 54.000 .000 & 14,80 \\
\hline & b. Pakan/Viatamin dan Obat-obatan; & & \\
\hline & Selama periode Starter ( 2 bulan) & 3.638 .250 & 1,00 \\
\hline & Selama periode Grower ( 5 bulan) & 27.920 .000 & 7,65 \\
\hline & Selama periode Finisher (8-9 bulan) & 31.905 .000 & 8,74 \\
\hline & Induk Betina (selama setahun) & 88.560 .000 & 24,27 \\
\hline & Pejantan (selama setahun) & 10.962 .000 & 3,00 \\
\hline & Vitamin \& Obat-Obatan (selama setahun) & 1.800 .000 & 0,49 \\
\hline & Jumlah (b) : & 164.785 .250 & 45,15 \\
\hline & c. Transportasi (selama setahun) & 54.000 .000 & 14,80 \\
\hline & d. $\quad$ Listrik + Air (Rp/Tahun) & 2.880 .000 & 0,79 \\
\hline & Jumlah Biaya Tidak Tetap : & 275.665.250 & 75,54 \\
\hline 3 & Total Biaya (Tetap + Tidak Tetap) : & 364.933 .180 & 100,00 \\
\hline \multirow[t]{3}{*}{4} & Rata-rata Biaya Per Ekor ; & & \\
\hline & Rata-rata Biaya Pakan Per Ekor & 513.350 & \\
\hline & Rata-Rata Total Biaya Per Ekor & 1.136 .863 & \\
\hline
\end{tabular}

Hasil analisis Margin Of Safety (MOS) sebesar 67,63\%, artinya apabila tingkat produksi mengalami penurunan sebesar $67,63 \%$ maka usaha peternakan babi tersebut masih berada dalam keadaan titik impas 
(tidak untung dan tidak rugi). Hal tersebut dapat diterangkan dengan nilai ROI yaitu, untuk mengetahui tingkat efisinsi dari modal yang telah dikeluarkan. Nilai ROI diperoleh nilai 1,51. Artinya penggunaan modal (biaya produksi) pada usaha peternakan babi "Kasewean" di
Tomohon sudah efisien atau memberikan tingkat keuntungan. Indikasinya bahwa usaha peternakan babi di perusahan Kasewean Tomohon mengalami keuntungan yang signifikan pada tingkat keuntungan per ekor sebesar Rp.580.932 per periode produksi.

Tabel 4. Hasil Analisis Break Even Point (BEP) dan Margin Of Safety (MOS) serta Return Of Investment (ROI) pada Usaha Peternakan Babi "Kasewean" Tomohon

\begin{tabular}{clr}
\hline No. & \multicolumn{1}{c}{ Uraian } & \multicolumn{1}{c}{ Jumlah } \\
\hline 1 & Jlh.Ternak (Ekor) & 321 \\
2 & Penerimaan (Rp/Tahun) & 551.412 .500 \\
3 & Penerimaan (Rp/Ekor) & 1.717 .796 \\
4 & Keuntungan (Rp/Tahun) & 186.479 .320 \\
5 & Keuntungan (Rp/Ekor) & 580.932 \\
6 & Biaya Tetap (Rp/Tahun) & 89.276 .930 \\
7 & Biaya Variabel (Rp/Tahun) & 275.665 .250 \\
8 & Total Biaya (Rp/Tahun) & 364.933 .180 \\
9 & Biaya Tetap Per Ekor & 278.093 \\
10 & Biaya Variabel Per Ekor & 858.770 \\
11 & BEP (Unit) & 103,92 \\
12 & BEP (Rupiah) & 178.509 .314 \\
13 & MOS (\%) & 67,63 \\
14 & ROI & 1,51 \\
\hline
\end{tabular}

\section{KESIMPULAN}

Berdasarkan hasil penelitian dapat disimpulkan bahwa :

1. Rata-rata biaya produksi usaha peternakan babi pada perusahaan "Kasewean" Kakaskasen II Tomohon sebesar Rp. 1.136.863 per ekor per periode produksi yang terdiri dari biaya tetap sebesar Rp. 278.093 dan biaya tidak tetap sebesar Rp. 858.770 per ekor per periode produksi. Penggunaan modal (biaya produksi) usaha peternakan babi pada perusahaan "Kasewean" di Tomohon sudah efisien dilihat dari nilai ROI sebesar 1.51. 
2. Usaha peternakan babi pada perusahaan "Kasewean" memperoleh keuntungan yang signifikan dilihat dari rata-rata keuntungan yang diperoleh sebesar Rp. 580.932 per ekor per periode produksi dan rata-rata keuntungan per bulan sebesar Rp. 15.539.943.

3. Usaha peternakan babi pada perusahaan "Kasewean" sudah mencapai bahkan sudah berproduksi di atas nilai titik impas pada volume produksi 103,92 unit atau 103 ekor dengan tingkat penerimaan $\mathrm{Rp}$. 178.509.314 per periode produksi.

\section{SARAN}

Berdasarkan hasil penelitian dapat disarankan bahwa perlu dilakukan kajian lebih lanjut secara menyeluruh tentang aspek-aspek sosial ekonomi dalam pengembangan ternak babi dalam hubungannya dengan pengalokasian sumberdaya milik perusahaan babi.

\section{DAFTAR PUSTAKA}

Aritonang. 2010. Beternak Babi

"Perencanaan dan Pengelolaan Usaha". Edisi Revisi. Penebar Swadaya . Jakarta.

Arikunto, S. 2002. Prosedur Penelitian, Suatu Pendekatan Praktek. Edisi Revisi V. BinaAksara. Yogyakarta.

Beattie, B.R. and C.R. Taylor. 1994. The Economic of Production. Terjemahan oleh $\mathrm{S}$. Josohardjono dan G. Sumodiningrat Cetakan I. Gajah Mada University Press. Yogyakarta.

Daniel M. 2001. Metode Penelitian Sosial Ekonomi. Umi Aksara.

Debertin, D.L. 1986. Agricultural Production Economics. Macmillan Publishing Company, New York.

Hardyastuti, S. 2011. Kajian Biaya Produksi Pada Usaha Peternakan Babi. Jurnal Sosek Peternakan Unibraw Malang. Volume 12 No. 1. Malang. 
Ibrahim, Y.H.M. 2003. Studi Kelayakan Bisnis. Edisi Revisi. PT Rineka Cipta Swadaya. Jakarta.

Santa N. 2012. Analisis Pendapatan Usahatani Ternak Babi di Kabupaten Minahasa. Jurnal Agropem, Volume 1 No. 1, Januari 2012. Manado.

Sihombing, D.T.H. 2010. Ilmu Ternak Babi. Gadjah Mada
University

Press.

Yogyakarta.

Singarimbun, M dan Effendi Sofian. 2009. Metode Penelitian Survey. Edisi Revisi. LP3ES, Lembaga Penelitian, Pendidikan dan Penerangan Ekonomi dan Sosial. Jakarta.

Soekartawi. 2001. Analisis Usaha Tani. Universitas Indonesia Press, Jakarta. 